\title{
RAMÓN GAYA, \\ EL PENSAMIENTO DE LA PINTURA
}

\author{
Elide Pittarello \\ (Università Ca' Foscari Venezia)
}

\section{Un camino aparte}

Ramón Gaya es un pintor, un poeta y un ensayista conocido, pero no tanto como para que sea superfluo recordar unos datos biográficos a la vez que voy esbozando su relación entre la pintura y la escritura. No seguiré un orden cronológico, sino una alternancia entre datos consolidados y detalles secundarios, confiando evidenciar algún aspecto de su obra que ha quedado un poco al margen de una bibliografía crítica extensa [Moreno Aguirre: 361-384]. Cito de entrada un fragmento de la presentación que Nigel Dennis antepuso al libro que recoge las entrevistas concedidas por Ramón Gaya en las últimas dos décadas del siglo pasado. No obstante la larga vida (Murcia 1910 Valencia 2005), el pintor no pudo ver publicados estos diálogos suyos, tan cruciales para ahondar en la cuestión de la imagen. A veces hasta una respuesta lapidaria confirma la necesidad de ampliar los marcos conceptuales para acercarse a sus cuadros y a sus páginas con instrumentos adecuados a su excentricidad. El hecho de haber conseguido cierto reconocimiento en un momento señalado de la historia política y cultural de España es parte del problema. La biografía ha acabado compitiendo con la obra y el supuesto pasadismo de su pintura es más bien un desacierto de una parte de los críticos. Como anota Nigel Dennis, a Ramón Gaya le tocó el papel del pintor esquinado durante décadas al que de pronto, en la Transición, se le hizo caso por encarnar el papel del testigo:

A partir de 1978, aproximadamente, fecha de una importante exposición suya celebrada en Madrid, la figura de Gaya — marginada o ninguneada durante los largos años del exilio e incluso después de su vuelta a España - comienza a despertar el interés de cierto sector del público, ansioso de recuperar 


\begin{abstract}
la memoria histórica del país de la cual el pintor constituía un elemento de indudable relevancia. En diversas ciudades — Murcia, Valencia, Madrid, Barcelona- acuden a verle periodistas y simples curiosos con el deseo de oír su testimonio sobre la Edad de Plata de la cultura española y de saber más de este "pájaro solitario" de la pintura contemporánea que, contra viento y marea, dentro y fuera de España, sin hacer concesiones a los modos y modas al uso, había seguido su propio camino, entregado totalmente a la tarea de realizar su obra [Gaya 2007:9].
\end{abstract}

Efectivamente, Ramón Gaya y su obra se convierten en un lieu de mémoire [Nora 1984: 23-43] con todos los riesgos que esto conlleva. Es un arma de doble filo por lo que se refiere a la valoración estética de una pintura figurativa difícil de encasillar, entre otras cosas porque el propio autor rechazaba algunos cimientos de la cultura occidental como el saber histórico y el paradigma del progreso con la respectiva tiranía de rupturas e innovaciones, bases de la escandalosa irrupción de la modernidad. Pero también echaba pestes de la estética que había encerrado las así llamadas "bellas artes" en la torre de marfil. No fue un conservador, ni se sumó a los "ismos" que se sucedieron con ritmo vertiginoso a partir del cubismo. Su cisma artístico pasó desapercibido, excepto para unos cuantos críticos. Entre ellos destaca Juan Manuel Bonet que, en su monumental Diccionario de las vanguardias en España (1907-1936), le dedica a Ramón Gaya una ficha larguísima —primer índice de un aprecio poco común— que empieza con esta definición: "Pintor, uno de los más solitarios y hondos que ha dado España a lo largo de este siglo" [1995: 285]. Once años después, siendo comisario de la retrospectiva de Ramón Gaya que se hizo en Barcelona, Bonet lamenta que el pintor no figure en el canon español. Aunque ya no lo incluye en las vanguardias, lo considera un excelente intérprete de la modernidad. Evidentemente, en su juicio, ésta no coincide con aquellas, las excede. Ramón Gaya había muerto hacía poco. Quizás también por eso el crítico abre el catálogo de la exposición con un beligerante y emocionado texto —un j'accuse en toda regla, titulado «Ramón Gaya: una travesía del siglo» - que recuerda cuándo y cómo ese protagonista de la España republicana y peregrina fue recibido en Madrid:

El comienzo del reencuentro de Gaya con un público español tuvo mucho de...encuentro, y me contagio de su estilo, de sus puntos suspensivos: hasta tal punto se había quebrado en nuestro país la continuidad histórica. Ese reencuentro se produjo en 1978, año de su retrospectiva en Multitud, galería madrileña de corta pero decisiva vida, ya que se especializó en la recuperación de la memoria de nuestra modernidad, entonces apenas visible para la historiografía. Los siguientes cinco lustros serían de afianzamiento de un público cada vez más amplio de gayistas confesos: pintores, historiadores 
y críticos de arte, conservadores de museos, galeristas, coleccionistas, escritores, editores de una nueva generación...La nómina, ciertamente extensa, de esos gayistas no la daré aquí, pues resulta demasiado extensa, y basta consultar las bibliografías. Sin embargo, inevitablemente, además de los ya mencionados Pre-Textos, hay que referirse al galerista y museógrafo Manuel Fernández-Delgado, propietario de Chys y alma del Museo Ramón Gaya de Murcia, inaugurado en 1990, además de comisario de algunas muestras de gran importancia simbólica, como las que en 1995 se le dedicaron en París y en Roma; a su marchand, el valenciano pascual Macià, ya citado a propósito de la exposición del San Pío V; y a dos poetas, Andrés Trapiello y Enrique Andrés Ruiz, que por encargo mío pusieron en pie las dos retrospectivas más importantes que se han dedicado hasta la fecha, el primero la del IVAM de Valencia, en el año 2000, y el segundo la del Reina Sofía, en 2003. (Frente a quienes supieron o supimos ver a Gaya, y decir esa admiración, corramos un tupido velo sobre quienes lo ignoraron, lo ningunearon o incluso, patéticamente — tratándose en algún caso de colegas suyos-, lo agredieron verbalmente cuando le concedieron sus dos grandes premios, no pretendidos sino caídos del cielo, y por lo demás ¡tan tardíos!: el Nacional de Artes Plásticas de 1997, y el Velázquez de 2002, que le entregó el Rey, en el Prado, en un acto de justicia histórica) [2006:32-34].

La práctica de la memoria tiene, entre sus fines, el de enmendar los olvidos o los fraudes de la historiografía pero, si bien Ramón Gaya siguió pintando hasta la muerte, el hecho de haber sido ajeno a las vanguardias históricas no dejaba de considerarse una equivocación por parte de sus detractores. Le reprochaban un tradicionalismo obsoleto, aunque la historia del arte del siglo xx, en palabras de Giuseppe Di Giacomo, «non ha fatto altro che dedicare le proprie energie alla distruzione di tutti i modelli di riferimento» [2015:3]. Lo que caracteriza la modernidad, añade el filósofo italiano, es la superación ininterrumpida de esos modelos, hasta el punto de que «è la rottura stessa a costituire la tradizione». Paradójicamente, concluye, «il "conformismo del non conformismo" è il circolo vizioso di ogni avanguardia» [2015:5]. Desde su primera juventud, Ramón Gaya estaba convencido de lo mismo. En 1995, entrevistado por Juan Manuel Bonet, traza este balance: «Todo es buscar algo que no se haya hecho todavía» [2007:370]. Cabe preguntarse, entonces, dónde situar a este pintor, puesto que dio la espalda a esos modelos cuando estaban en auge, pronosticando su transitoriedad. Había regresado a España al comienzo de los setenta. La exposición retrospectiva de 1978 inauguraba el proceso del desagravio histórico que incluía también la publicación de escritos como Diario de un pintor (1952-1953), inédito hasta entonces. A partir de 1984, la editorial PreTextos daría a la imprenta su obra completa —ensayos, poemas y cartas — recuperando textos que habían sido publicados de manera episódica, pero sobre todo dando a conocer por primera vez lo que el autor tenía guardado desde hacía tiempo. 


\section{Si hubiera sido italiano}

La historia de las artes está constelada de autores incomprendidos. Algunos lo fueron toda la vida, otros sólo en sus comienzos. Baste con recordar que Vincent Van Gogh no consiguió vender un solo cuadro o que Marcel Proust tuvo que costearse la publicación de la primera entrega de la Recherche. La lista es larga y sintomática del desfase que puede producirse entre el creador y su público por el papel que desempeñan los intermediarios. A veces hay que cambiar de país, aunque no es ninguna garantía. Por ejemplo Vladimir Nabokov, que en el exilio eligió escribir en inglés, consiguió publicar Lolita en Francia tras el rechazo de varias editoriales de Nueva York. En cambio el griego Jannis Kounellis, rechazado por la academia de su país, al establecerse en Italia se convirtió en uno de los artistas más reputados del movimiento Arte povera, una neo-vanguardia. No fue este el caso de Ramón Gaya, a pesar de haber vivido tantos años en Roma. Con respecto a los experimentalismos de los años cincuenta y sesenta, también allí su pintura figurativa nacía a destiempo. Sin embargo, Juan Manuel Bonet se figuraba para él una mejor fortuna de haber nacido en alguna pequeña ciudad italiana donde hubo artistas que pintaron a contracorriente. En un artículo de 1995, abogando por una articulación más flexible del concepto de modernidad, el crítico anotaba:

\footnotetext{
sólo algunos modernos sectarios y recalcitrantes siguen negando, contra toda evidencia, la existencia de una tradición figurativa moderna que nada tiene que ver con la supervivencia del naturalismo decimonónico. Sabemos que lejos de reducirse a la historia de la rápida sucesión de las vanguardias, la historia del arte contemporáneo es también esa historia otra, esa historia en la que, de repente, un pintor silencioso, Filippo de Pisis, Giorgio Morandi, Ramón Gaya, reinventa, en la calma de Ferrara, de Bolonia, de Murcia, la pintura, apoyándose en unas flores, en unas botellas, en una copa de agua [2005:47-48].
}

Efectivamente, a diferencia de Giorgio Morandi —el esquivo pintor de botellas y tazas evanescentes, tan alejadas de la estética vanguardista - en su plenitud creativa Ramón Gaya no pudo contar con la admiración de alguien autorizado como Roberto Longhi, que lo incluyó en el canon cuando tenía poco más de cuarenta años. Es significativo el hecho de que el crítico y académico italiano sellara la prolusión al curso de historia del arte de la universidad de Bolonia, en el año 193435, afirmando que Morandi era uno de los mejores pintores vivientes, no obstante las insidias de la pintura moderna [1973:217]. Por haber nacido en España y haber vivido un largo exilio, Ramón Gaya tuvo otro destino. Lo recuerda Juan Manuel Bonet en el íncipit del texto que abre el catálogo 
de la retrospectiva del 2006: «Siempre se ha dicho aquello de "si José Gutiérrez Solana hubiera sido francés...". ¿Qué habría que decir en el caso de Ramón Gaya (Murcia, 1910-Velencia, 2005)? ¿Si hubiera sido italiano?» [2006:11]. Tras un breve bosquejo de su trayecto artístico, el crítico recuerda nuevamente que, cuando al pintor se le concedió el premio Velázquez en 2002, el consenso distaba mucho de ser unánime:

\footnotetext{
hubo un coro, pequeño pero malévolo, de voces en contra, que no soportan ese modo suyo, intenso y libre, otro, en definitiva, de vivir el siglo de siglas. Más allá de cualquier polémica de vía estrecha, tengo clarísimo que si Ramón Gaya hubiera sido italiano... formaría parte, sin dejar de ser polémico, sin dejar de ser discutido, que eso no es lo fundamental, de la tradición moderna, del canon de su país, como ineludiblemente formará parte de los nuestros, el día en que dejemos de entender la modernidad como una única autopista y asumamos de una vez por todas que hay muchos caminos [2006:11-12].
}

Mientras tanto hay otra manera de ver a Ramón Gaya como un artista acorde con nuestro tiempo, precisamente por su manera heterodoxa de vincularse al pasado de la pintura. Siendo para él un ente originario que aflora en la imagen del pintor que se ponga a su servicio, el arte de Ramón Gaya puede incluirse en la contemporaneidad si se ubica en el marco conceptual elaborado por Giorgio Agamben. De entrada hay que rebasar el orden cronológico del tiempo, sustituyéndolo por una relación dialéctica entre lo moderno y lo arcaico:

\footnotetext{
La contemporaneidad se inscribe, en efecto, en el presente, signándolo sobre todo como arcaico, y sólo aquel que percibe en lo más moderno y reciente los índices y las signaturas de lo arcaico puede ser contemporáneo. Arcaico significa: próximo a la arché, es decir, al origen. Pero el origen no se sitúa solamente en un pasado cronológico: es contemporáneo al devenir histórico y no cesa de operar en éste, como el embrión continúa actuando en los tejidos del organismo maduro, y el niño, en la vida psíquica del adulto. [...] Los historiadores de la literatura y del arte saben que entre lo arcaico y lo moderno hay una cita secreta, y no tanto porque las formas más arcaicas parecen ejercer sobre el presente una fascinación particular, sino más bien porque la clave de lo moderno está escondida en lo inmemorial y en lo prehistórico [2011:25].
}

Desde muy joven, Giorgio Agamben fue un admirador y amigo de José Bergamín. Es otro italiano que en Roma no solo tuvo trato con Ramón Gaya, sino que se alojó durante diez años en uno de sus estudios, cuando el pintor había vuelto a España pero sin abandonar Italia. El filósofo italiano 
lo recuerda en un singular y refinado texto autobiográfico, Autoritratto nello studio, que reproduce también uno de los cuadros difuminados de Ramón Gaya. Es el Autorretrato con metrónomo, de 1979: en escorzo, el rostro del pintor se refleja parcialmente en un espejo antiguo, con un gran marco y el cristal algo picado. En cuanto parte de una composición doméstica, típica del pintor, el espejo está posado encima de una repisa, cubierta con una tela. El espejo comparte la superficie con una tacita de porcelana con flores blancas, una pequeña caja dorada, un vaso de agua, tres granadas, un abanico y un metrónomo: citas o topoi icónicos muy familiares, como se verá más adelante. El cuadro interactúa con las líneas que Agamben le dedica al pintor:

\footnotetext{
È stato José Bergamín, durante uno dei nostri incontri madrileni, a presentarmi Ramón Gaya, che mi ha generosamente prestato lo studio di vicolo del Giglio in cui ho scritto e abitato per circa dieci anni a partire dal 1978. Che il mio secondo studio fosse stato lo studio di un pittore - come il primo in piazza delle Coppelle era stato quello di uno scrittore - che io vi abbia sempre lasciato come I'avevo trovato un cavalletto con un quadro incominciato, ha certamente a che fare col mio amore per la pittura, quasi che ci si passasse tacitamente una consegna. Ricordo ancora la naturalezza con cui Ramón, che aveva lasciato il suo studio già da due anni per quello che credeva un breve viaggio in Spagna, mi disse che potevo usarlo come volevo. Seppi più tardi che durante la Guerra Civile aveva perduto tutto, la sua casa, i suoi quadri, la moglie, morta in un bombardamento fascista alla stazione di Barcellona dove Ramón sperava di raggiungerla, la figlia —miracolosamente strappata da due inglesi dalle braccia della madre— che poté rivedere solo quindici anni dopo [2016:19].
}

No es casual que en el catálogo de la retrospectiva de 2006 figure un precioso texto de Agamben, titulado «El lugar de la poesía. Aproximaciones a la poesía de Ramón Gaya». En una breve premisa sobre la metafísica originaria del ser que funda la poética del autor, según el filósofo italiano «se puede afirmar de los escritos de Gaya lo que se ha afirmado de los aforismos de Nietzsche: a saber que, aunque son asistemáticos y fragmentarios, contienen más rigor que muchos tratados de estética» [2006:49]. Ramón Gaya dio con la obra de Nietzsche en la biblioteca del padre, empezó a leerlo desde que era un niño y siguió siendo para él una referencia constante. Tuvo siempre consigo una foto suya, le dedicó homenajes, lo citó en ensayos y entrevistas [Moreno Aguirre 2016:61-60]. Según Antoine Compagnon, Nietzsche fue uno de los «fundadores de la tradición antimoderna que recorre toda la modernidad» [2007:217]: para el pintor, se trataba de una compañía excéntrica prestigiosa. 


\section{Con palabras propias}

La cuestión de la modernidad de Ramón Gaya queda abierta también para un filósofo español, José Luis Pardo. En el catálogo de misma exposición escribió un texto — «Ramón Gaya o el nacimiento de la pintura»— que me parece imprescindible para ahondar tanto en las intenciones éticas del pintor como en la relevancia estética de su obra y la problemática relación con el canon. El punto de partida es la pervivencia de tópicos inadecuados para afrontar estos asuntos con perspectivas que estén a la altura de las circunstancias. Si Ramón Gaya es un caso por no haber querido ser novedoso y tampoco tradicionalista, habrá que interpretarlo con la conciencia de que el paradigma crítico dominante ha decaído y probablemente sea irreemplazable. Al lado del concepto de contemporaneidad de Agamben, piénsese, por ejemplo, en el «régimen de historicidad» de François Hartog, que evidencia «diversos modos de relacionarse con el tiempo: formas de la experiencia del tiempo, aquí y allá, hoy y ayer» [2007:30]. En la manera de asumir el pasado, ni hay un tiempo único, ni un cuestionamiento independiente del observador. Lo que interesa es que Ramón Gaya lo haya sabido y puesto en práctica por su cuenta desde que era poco más que un niño, en los años '20 del pasado siglo. Fue una vivencia ajena a proclamas y manifiestos. Como dijo en muchísimas ocasiones, se dio cuenta de que su camino era otro cuando, en 1928, viajó a París por primera vez, con diecisiete años y medio, en compañía de los pintores Luis Garay y Pedro Flores [Valcárcel 2011:50-57]. La estancia fue inolvidable porque marcó para siempre el rumbo de su arte. En una entrevista de 1988 con Andrés Trapiello, sesenta años después el pintor así recuerda la caída de las ilusiones:

\footnotetext{
A mí me impresionaron menos las cosas cuando las vi allí, directamente, que cuando las habíamos visto en Murcia, en las reproducciones de los libros. Es decir, que todas esas vanguardias que desde mi rincón de Murcia me había bebido con ansiedad, al verlas directamente se me cayeron un poco... Como era muy joven, no me atrevía a hablar de todo esto con Flores y con Garay: ni siquiera me atrevía a confesármelo a mí mismo. Era casi un drama para mí. [Gaya 2007:263]
}

Hay que dar por sentado que su orden del tiempo no está representado por la metafórica flecha, cada vez más acelerada hacia un porvenir brumoso. No es que él no tuviera en cuenta el futuro. Todo lo contrario. Pintando como pintaba, atendió toda su vida a un compromiso acuciante, el del testigo que acepta el legado de un tesoro que tiene que seguir viviendo, es decir formando parte de la vida de cada uno. El pintor se pone al servicio de la pintura. José Luis Pardo, que apunta 
a comprender la singular modernidad de este artista, ironiza sobre quienes esgrimen las vanguardias como granítico criterio de valor, sin percatarse de su obsolescencia:

\begin{abstract}
Ramón Gaya expresaba a menudo con tanta honestidad como sarcasmo, su compasión por algunos de sus compañeros de generación, «tan viejecitos y todavía empeñados en ser revolucionarios». Pero al hacerlo, no sé con qué grado de consciencia, expresaba también la misma maldición que pesaba sobre él, obligado hasta el final a ser «revolucionario» (o sea, «transgresor»o «blasfemo») de la única manera que es posible serlo en un orden estético donde las vanguardias han dejado de ser tales y se encuentran completamente institucionalizadas y perfectamente integradas en los mecanismos de poder intra-artísticos y extra-artísticos que dominan lo que él llamaba el tablero del arte (es decir, a la vez el mercado y el discurso crítico que sostienen a las obras en cuanto tales): transgrediendo la ley que ordena ser transgresor a cualquier precio [2006 60].
\end{abstract}

La transgresión de Ramón Gaya es tanto más vistosa si se la compara con los avatares del arte en el siglo XX. En España, quienes seguían abaratando su obra en aras de una estética que relegaba el figurativismo a una tradición fósil, no parecían haberse enterado de que ya no era vigente el relato que legitimaba lo que era o no era arte. A finales del siglo pasado, Arthur C. Danto, el teórico del fin (del relato) del arte, acontecimiento que él fija en los años '60, observaba que «la conexión entre arte y estética es una contingencia histórica y no forma parte de la esencia del proprio arte» [Danto 2014:54]. Se hacía arte antes y se sigue haciendo arte después, en ausencia de preceptivas generalizadas y encarando la globalización y la transmedialidad. Es útil hacer esta puntualización para acoger el pensamiento de Ramón Gaya, tan contrario a cualquier estética de la pintura, al margen de una doxa ya relativizada. En "Carta a un Andrés», un texto fundamental de 1978 — subrayo la relevancia de la fecha, es el año de la exposición madrileña que le dio una visibilidad tardía— Ramón Gaya expone su concepción de la pintura. Ni mimética ni historiable, la pintura es para él una forma de vida que no cabe en el marco de una modernidad entendida como emancipación de los valores tradicionales y el encumbramiento de lo contingente y lo transitorio:

\footnotetext{
No, amigo Andrés, yo no he dicho que la "modernidad" no exista, sino tan sólo que...no importa, que no puede importarnos, porque eso, "eso" tan endeble, tan de superficie, tan de pasada, que llamamos "modernidad", no tiene valor proprio, valiosa sustancia propia. La modernidad no es, no puede ser — nunca — valor, como estúpida, frívola y descuidadamente hemos terminado por suponer, la modernidad no puede ser más que un simple estado por el que pasan - y pasan irremediablementelas más o menos pobres obras de arte nuestras, pero sin formar parte — carne - de ellas [Gaya 2010:189. Cursivas del autor].
} 
Lo más interesante viene a continuación. Tras ulteriores desdenes de las prescripciones de la modernidad ortodoxa, Ramón Gaya reivindica para sí mismo una forma de modernidad alternativa que entronca con el pasado de la pintura para traerlo nuevamente a la presencia, no como mímesis sino como aparición. Afirma Inmaculada Murcia Serrano que moderno «significa, pues, para Gaya "presente", pero en el sentido de intemporal» [2011:50]. La modernidad es el legado de un ente —la pintura — que, ajeno a la estética y a la historia del arte, enlaza con la existencia del viviente:

\footnotetext{
Claro que existe... otra cosa — una especie, diríamos, de energía soterrada - que acaso también puede (y con mayor motivo) ser considerada "modernidad", pero no es, entonces, en absoluto, esa petulante modernidad exterior, vistosa, brillosa, fugacísima, que todos sabemos, sino otra más secreta, más verdadera: es una modernidad que no consiste en ir sacándose de la manga, sin ton ni son, míseras novedades pueriles, tontas, tontucias, sino de dar vigorosa vida sucesiva a lo de siempre, a lo fijo de siempre. Porque si "clásico no es más que vivo", moderno no puede ser más que vivo también; pero claro, vivo de...vida, de vida vivida, sanguínea, no de esa seudovida — que no es más, en realidad, que una pobre agitación, un simple trajín, un ir y venir vacío, en el vacío-, no de esa seudovida activa que el historiador — todo historiador - confunde y toma siempre, sin remedio, por la misma vida central, real y verdadera [Gaya 2010:189-190. Cursivas del autor].
}

Esta aserción sintetiza lo que Ramón Gaya había ido escribiendo sobre la ontología y la misión de la pintura desde el texto Homenaje a Velázquez (1945) a El sentimiento de la pintura (1960), ensayo basado en parte en las anotaciones del Diario de un pintor (1952-1964). Sucesivamente redacta Velázquez, pájaro solitario, cuya primera versión, de 1963, obtiene un premio en Italia como manuscrito inédito. Este texto, que se publicaría ampliado en 1969, y los escritos anteriores están ahora reunidos en la Obra Completa [Gaya 2010]. Al llegar a Venecia por primera vez en verano de 1952, tras trece años de exilio en México, Ramón Gaya deja constancia de su deslumbramiento en anotaciones metafísicas que van en dirección contraria al conocimiento histórico y filológico del arte. Cuaja entonces, en ese lugar, una revelación de la pintura que Ramón Gaya irá puliendo con el fervor de un creyente. El enfoque original requiere un léxico hecho a medida y, como suele pasar cuando se afrontan lingüísticamente situaciones impensadas, el gran recurso estilístico es la metáfora. Citando a Aristóteles, según el cual la metáfora pone ante los ojos las cosas en acto, Paul Ricoeur insiste en la poiesis de este tropo, en su creatividad en el ámbito del discurso. La metáfora ofrece imágenes inéditas del mundo [1975:61]. En este sentido la usa Ramón Gaya al configurar la pintura 
como un fenómeno originario y atemporal, una fuerza que fluye en forma subterránea y acuática para manifestarse en la obra de algunos pintores. Los elegidos, todos excelentes, se ajustan al criterio personal del pintor, quien excluye nombres ilustres, a veces con descalificaciones inapelables. Al fijar por escrito el efecto que le causa la visión de los cuadros de Giovanni Bellini, Ramón Gaya acuña en Venecia los términos fundamentales de su discurso, los que a partir de entonces volverá a emplear una y otra vez con ulteriores metáforas:

\footnotetext{
Bellini no es Tiziano —aquí, Bellini parece el Bautista—, pero...casi lo es, y más que anunciarlo, nos lo...entrega. No, no es un precursor - no creo en los precursores, y en realidad no existen: creo en la pintura, en la sustancia y el...sentimiento de la pintura, de una pintura sola y única, vívida, siempre impertérrita; y creo en...su paso, en su ir, subterráneamente, pasando-. En Bellini, la pintura —la Pintura — pasa por él — con su carnosidad de...agua subterránea—, aunque, claro, no se embalsa, no se ensancha, como sucede cuando ésta desemboca en un Sesshu, en un Tiziano, en un Velázquez, en un Rembrandt [Gaya 2010:402. Cursivas del autor].
}

Al igual que María Zambrano, con quien había estrechado amistad desde los años de la juventud republicana, Ramón Gaya concibe la pintura como un arte de la revelación que raya en lo sagrado: «Lo veneciano, en pintura, no es una escuela, ni siquiera un concepto nuevo, distinto, de lo pictórico, sino una...reaparición de lo pictórico, perenne, fijo, original, originario» [Gaya 2010: 402]. Cuando regresa a Venecia seis meses después, la ciudad se le presenta como un «lugar» de la pintura, una patria sui generis para el exiliado. El 23 de enero de 1953 escribe en su diario:

\footnotetext{
Creo que me encuentro, casi sin querer, aquí en Venecia, y no en Florencia o Roma, porque Venecia es un lugar de pintura, un suelo suyo, un pedazo de tierra firme suya. Florencia o Roma podían, quizá, ofrecerme unos temas, unos motivos pictóricos más corpóreos o menos ilusorios, menos...venenosos, pero yo no he venido en busca de tema, sino de tierra, de esa tierra húmeda, acuosa, lagunosa, de la pintura. Durante demasiado tiempo —ahora veo que mi exilio en México ha durado más de trece años- me había sentido...como desterrado, y no ya de mi país, o de Europa, sino de esa otra patria soterrada, más sustancial, que viene a ser, para un pintor, la Pintura [Gaya 2010:429].
}

Estas líneas son especialmente significativas. Testimonian el arraigo de una actitud metafísica, móvil del deseo que cuenta con la inaccesibilidad de su objeto, con su más allá inencontrable. Un tipo de deseo que es apertura hacia la trascendencia e implica la llamada y la vocación, la espera y 
la rebeldía [Recalcati 2012:118-123]. Es así como Ramón Gaya transfigura su exilio y simbólicamente lo perpetúa. Dijo Vladimir Jankélévitch que «l'amour, comme la nostalgie, fabrique des lieux saints» [1974: 277]. Desplazando al ente sagrado — a la pintura amada — la añoranza del lugar propio, Ramón Gaya se pone en la condición de estar siempre en camino hacia el lugar de origen adonde no volverá jamás. En 1989, a un periodista de Murcia que le pregunta por qué no ha vuelto a vivir en su ciudad natal, el pintor contesta lo siguiente: «Mi experiencia del exilio en México me ha enseñado una cosa: lo que yo entiendo por mi casa es Europa. De ninguna manera es ni Valencia, ni Murcia, ni Madrid, ni Segovia, gustándome mucho todos esos sitios» [Gaya 2007:299]. Es una manera de aludir al hecho de que para él el exilio ha llegado a ser una forma de vida y una pauta de conducta habituales, forjadas también lingüísticamente a partir de las estancias venecianas. Si, como dijo Wittgenstein, "hablar el lenguaje forma parte de una actividad o de una forma de vida» [2010:39], aquellos enunciados novedosos del Diario de un pintor esbozan un paradigma artístico y ético fundados ya para siempre en la que Jankélévitch clasificó como la «existence expatriée» del errante apegado a su errancia [1974: 295]. Lo confirma Andrés Trapiello, quien dijo que Ramón «vivió con mayor naturalidad, y hasta bien entrada su edad madura, su ambulancia de aquí para allá, sin casa propia, en pensiones, hoteles y pisitos o estudios prestados, arrastrando todo cuanto tenía en un par de maletas, la de la ropa y la de la obra» [2010:175]. Es otra característica del antimoderno, un desarraigado que, al no ser tradicionalista, «seguirá siendo un exiliado interior» que «no tiene casa, ni mesa, ni cama» [Compagnon 2007:31].

Estar de paso, estar siempre en movimiento es una experiencia en devenir que ata el cuerpo del pintor a las artes de pintar y escribir. Por ejemplo, piénsese en el cuadro que titula Nacimiento de la pintura (1958), donde se ve una mujer de perfil saliendo de las aguas turbias, de tonos marrón y ocre, de un canal veneciano. En El sentimiento de la pintura Ramón Gaya rememora la génesis del cuadro, una aparición surgidas de las aguas que forman una mitología personal, que afecta a sus sentidos: «Un atardecer, de entre aquellas aguas espesas, usadas, me pareció ver salir, surgir como una Venus cochambrosa, el manchado cuerpo de la Pintura» [Gaya 2010:43]. En Venecia el pintor acuña un discurso sobre la pintura que no abandonará jamás. Transfigurada en topos metafísico, visualizada con otras imágenes, Venecia condensa lingüísticamente la concepción de una pintura ajena a la estética y a la historia del arte, un ente originario y vivo, exento de cronología: «Puede decirse que Venecia lo que hizo fue ceder a la pintura, acoger a la pintura, el sentimiento originario, 
vivo — no artístico - de la pintura. Venecia no era, pues, una escuela, una manera, una tendencia, ni siquiera un orden, una ley, sino un lugar, una atmósfera propicia, un criadero, un vivero» [Gaya 2010:41]. La palabra clave es «lugar», un más allá natal que localiza el deseo. Presupone el retorno nostálgico y a la vez lo mantiene en suspenso a través de la propia práctica de la pintura, que para Ramón Gaya es una búsqueda incesante de la aparición.

Es interesante recordar que María Zambrano, después de regresar a España tras el largo exilio, decide recoger sus numerosos escritos sobre pintura —el primero es de 1933, el último de 1989—, Ilamando el libro Algunos lugares de la pintura [Zambrano 2012]. No parece un título casual. En 1953 Ramón Gaya vuelve a México, el mismo año en que María Zambrano deja La Habana y se establece en Roma. En 1956, abandonado México definitivamente, Ramón Gaya hará lo mismo. En la capital italiana los dos se ven casi a diario y frecuentan un círculo selecto de amistades formado por Elémire Zolla, Cristina Campo, Elena Croce, Nicola Chiaromonte, Pietro Citati entre otros. No es extraño que Zambrano y Gaya lleguen a compartir tanto la visión metafísica de la existencia como ciertas afinidades en el lenguaje [Durante 2013:105-116]. Por lo que atañe exclusivamente a la pintura, en un texto de 1959, «Mitos y fantasmas de la pintura», María Zambrano se refiere a este arte en términos que no había usado antes. Primero compara la pintura con el fantasma, «un ahogado en el tiempo, en el río del tiempo sucesivo que logra asomarse un instante a la superficie antes de que se lo trague la corriente»; luego la define «un extraño fluir que permanece, un río temporal que se queda; no una forma de estar, sino del pasar, del pasar a...ser o hacia el ser más que hacia la realidad» [Zambrano 2012:44].

Desde una perspectiva que la acerca al planteamiento de los Visual Studies, centrados en la reacción del espectador, por primera vez la filósofa se refiere a la pintura con imágenes análogas a las que había inventado Ramón Gaya, el cual por aquellas fechas estaba ultimando El sentimiento de la pintura. Sobre el trabajo que le costó la redacción de este texto, por lo general ignorado no obstantes las reseñas entusiastas de Cristina Campo y Pietro Citati, remito a lo que escribe Laura Mariateresa Durante en la introducción a su nueva traducción italiana del ensayo [2015:44-52]. En 1960, el mismo año en que el pintor publica El sentimiento de la pintura en Italia y en España, Zambrano publica en Ínsula «La pintura de Ramón Gaya» [2012:144], un largo y elogioso artículo donde las coincidencias terminológicas son manifiestas. Destaco el reconocimiento del rol del pintor: él no hace otra cosa que 
ser el trámite de la pintura, posibilitando su aparición con una actitud sacrificial. En los canales de Venecia, afirma Zambrano, Gaya descubre que la pintura viene del agua [Pittarello 2017:161-162].

Surgió allí el compromiso de este pintor con una modernidad excéntrica. Al afirmar que la pintura no es representación sino vida o energía que preexiste al pintor y lo atraviesa, coincide con las vanguardias por lo menos en rechazar el arte por el arte junto con el rol del artista titánico, genial. En El sentimiento de la pintura Ramón Gaya diferencia al artista-pintor, que se reconoce «por ese carácter de travesura que tiene casi todo el arte moderno, ya que se trata de un arte especialmente artístico, artificial», del creador-pintor, tan solo «conforme» con sus habilidades por «ser vasallo, ser siervo del sentimiento pictórico» [Gaya 2010:40]. Subraya José Luis Pardo que la obra de Ramón Gaya «está destinada a convivir estética e institucionalmente con todo aquello de lo que más intensamente desearía distinguirse» [2006:70]. Sin embargo, lo hace invirtiendo el camino, ya que «mientras la inmensa mayoría de las artes visuales de nuestros días han elegido escenificar dramáticamente lo que podríamos llamar la muerte de la pintura, los cuadros de Gaya (empezando por su obstinado apego al formato) ponen contantemente en la palestra su nacimiento» [2006:71]. Huelga añadir hasta qué punto es indispensable la escritura del pintor, más centrada en las imágenes que en los conceptos, para interpretar su obra pictórica. De la imagen pintada a la imagen escrita y viceversa, dos visiones entrelazadas. Louis Marin ha puesto en evidencia el estrecho parentesco entre la imagen y el lenguaje, en el cruce semiótico y emocional que cuestiona el predominio del sujeto sobre el objeto. Las imágenes atraviesan los textos y los modifican. A raíz de esta acción, los textos acaban transformando las imágenes [1993:9]. El tránsito o vaivén entre lo que Ramón Gaya pinta y escribe le da al espectador unas herramientas hermenéuticas decisivas. Gracias a ellas, puede engarzar la aparición en la mímesis, captando lo que a primera vista sus ojos —educados por el concepto dominante de la modernidad — no alcanzarían.

\section{Documentos, huellas}

Antes de convertirse en un topos de sus escritos y una constante de sus cuadros, la pintura como aparición es para Ramón Gaya una experiencia temprana, anterior a la del exilio. No tiene connotaciones dolorosas, pero la nutre ya el deseo de un más allá artístico —una alteridad pictórica— que estructura la busca de lo que siempre se le sustrae. Es una distancia que, en circunstancias 
diferentes y con distintas acepciones, no desvanecerá. En Murcia, el pintor adolescente está lejos de los cuadros de los que se habla tanto en tiempos de vanguardias. Hago hincapié en el rol que la reproducción de obras pictóricas ha desempeñado en su trayectoria artística desde el comienzo. Cada reproducción es un documento, en palabras de Maurizio Ferraris un objeto social que es registrado en algún soporte [2017:20] y que «constituye la génesis de la intencionalidad individual» [2017:22]. En Murcia el catálogo de arte vanguardista es para el pintor en ciernes el documento por antonomasia. Le abre horizontes inesperados, fomenta su fantasía, se convierte en seguida en algo familiar que entra en su pintura al lado de los objetos de la vida cotidiana: una constante en su pintura. En el Bodegón de 1926, de tonos claros y apagados, un catálogo grande, abierto en primer plano, comparte el espacio de la mesa con una manzana y algunos utensilios de cocina: una cuchara de madera, un tazón de barro, un paño blanco. En El azucarero, otro bodegón de 1927 donde domina la gama del ocre y el castaño claro, junto a la vajilla de barro que está encima de una americana arrugada, destaca la cubierta colorada de un libro. Tiene el formato de un catálogo de arte, esta apoyado verticalmente en el respaldo de la silla modesta que acoge toda la composición. El pintor adolescente ha abolido la jerarquía axiológica entre el quehacer artístico y la vida doméstica. Ya entonces ha configurado un «lugar» de la pintura. Estos dos bodegones testimonian el vínculo temprano de su arte con la realidad del cuerpo y del habitar, con las moradas del viviente que es un pintor. De momento, este vive en una ciudad de provincia, está lejos de los cuadros que ansía ver en persona.

En el gran número de entrevistas concedidas por Ramón Gaya, que Nigel Dennis recogió en el libro ya mencionado, asoma continuamente el nexo insoslayable entre arte y vida. En 1989, a Ignacio Vidal Folch que le pregunta por la evolución de la pintura, Ramón Gaya resume su punto de vista exaltando la importancia de los lugares donde pintaba. Luego, acudiendo a un silogismo, esgrime una inferencia estética, es decir el escaso valor de la pintura abstracta que prescinde del cuerpo de las cosas:

\footnotetext{
Creo que lo último que ha hecho la vanguardia es el cubismo. Era una forma nueva de ver y concebir el cuadro, pero esa revolución se hacía aún dentro de la pintura, dentro de una substancia pictórica. Y ya no se puede ir más allá, porque nos saldríamos de la pintura. Y es importantísimo que la pintura sea pintura, la poesía, poesía, y la música, música, porque las obras son la corporeidad necesaria para que aparezca el espíritu. Y es que el espíritu, para aparecer, necesita carne. Hay varias clases de carne o de corporeidades — la pintura tiene la suya - que proceden y deben ir ligadas a la vida, deben brotar de ella. Por ejemplo, yo no puedo pintar en un estudio separado del lugar donde hacemos la
} 
vida. Por eso, creo que esa separación de la vida hace que el arte abstracto no lleve a ninguna parte [Gaya 2007:293].

Guardemos este acoplamiento entre pintura y vida que conecta el sentir, el saber y el hacer de Ramón Gaya, y volvamos al Bodegón de 1926, con la imagen del catálogo tan evidente en la sintaxis figurativa del cuadro. En Murcia, Ramón Gaya no tiene más remedio que ser el espectador de las fotos de los catálogos de arte, con todo lo que esto implica. La foto es el simulacro del objeto fotografiado, es el eidôlón emitido o el Spectrum del referente [Barthes 1989:35]. Esa imagen fantasmal tiene una función creadora si el sujeto la inmortaliza en una forma [Tisseron 2000:42]. Para Ramón Gaya, pintar en el Bodegón de 1926 la imagen del catálogo abierto con la foto de una pieza vanguardista, es concretar su deseo de inscripción en un ámbito prestigioso del que espera formar parte un día. En esa visión pintada late la huella personal (el bodegón) de un rastro ajeno (la foto del catálogo). Entre el documento real y su apropiación pictórica media una ensoñación que se desmorona al cobrar realidad. Como dijo en muchísimas ocasiones, lo que el joven artista había imaginado no corresponde a lo que luego vio en 1928 en París.

En cambio, es muy otra su reacción frente a algunos cuadros del Louvre. Su independencia de juicio en seleccionar a los pocos pintores que le gustaban se manifestó ya entonces, con un asombro entusiasmado. La contemplación en directo, no mediada por las reproducciones, produjo vuelcos decisivos en su práctica de la pintura. El asombro erosiona la identidad, dijo Aldo Gargani, porque Ileva uno a reconocer que no es el que creía que era, a la vez que pone en marcha «il sentimento di essere aperti a una consonanza, mai conclusiva, occasionale, fortuita con l'esperienza esterna, con i luoghi della nostra vita» [1986:12]. Más tajante es la definición de María Zambrano: «El asombro es pasmo, el pasmo que se da cuando se vislumbra algo insólito, pero que es aún más puro y fecundo cuando se produce ante algo de sobra conocido y que de repente se presenta como nunca visto» [1989: 99]. En el ensayo Velázquez, pájaro solitario, Ramón Gaya usa el mismo lexema — «pasmo»— para expresar la reacción que tuvo al ver por primera vez los cuadros de Velázquez [2010:97]. Pero retrocedamos a un artículo que publicó en el periódico madrileño Luz, el 1 de agosto de 1934, cuando era un activista veinteañero de la juventud republicana. Se titula «Diario de un pintor: La bondad y Velázquez» y empieza así: 


\begin{abstract}
Cuando entré por primera vez en el Museo del Prado tuve grandes sorpresas. Goya, a quien más estimaba (tenía yo diecisiete años entonces), me decepcionó mucho. Velázquez en cambio, se me reveló, si no por completo, gran parte de él, y presentí todo lo que había de ser para mí más tarde. No he tenido que cambiar mi primera impresión o emoción ante Velázquez; ha crecido, se ha desarrollado, pero todo lo que encontré en su obra la vez primera me sirve hoy, es lo mismo, solamente que con más riqueza [Gaya 2010:694].
\end{abstract}

Es un testimonio coherente con la juventud del autor. Pero veamos cómo cambia la calidad del relato al rememorar el mismo acontecimiento en un texto empezado en el exilio mejicano en 1950 y terminado en Madrid en 1991, cuatro décadas en las que había sorteado muchas vicisitudes. El breve texto, que se titula «Entrada en Madrid de un pintor», vuelve a proponer el acceso a la pintura como una experiencia que se parece a la revelación mística, recordando la pobreza de las reproducciones vistas con anterioridad. Es sintomático que no omita la mención de estos documentos. Registrando imágenes de imágenes, las reproducciones le habían adelantado la huella de lo que ansiaba conocer mientras estaba lejos. El hecho de que esa visión quede radicalmente modificada al contemplar los cuadros en directo no hace otra cosa que subrayar la vivencia permanente de la distancia con respecto al objeto deseado. Cuando termina este texto, ya ha acumulado una larga experiencia de esa falta o nostalgia inscrita en las reproducciones de las que se ha ido rodeando a lo largo de su vida:

\footnotetext{
En enero de 1928, casi un niño todavía, entraba yo temblando, sin respiración, sin aliento, en el Museo de más ... sustancia pictórica que existe. Sabía muy bien, por reproducciones y libros, lo que encerraban aquellas salas — por aquel entonces muy silenciosas y casi desiertas_-, pero ahora lo que tenía ante mí no eran ya unas simples estampas planas, aplastadas, sin vida, sino la misteriosa verdad directa de la Pintura. Los cuadros no eran esa "superficie animada" que tan tontamente se nos dijo ser; no, no eran lienzos cegados, pintarrajeados por Poussin o por Mondrian, sino sencillísimas ventanas de par en par, abiertas al infinito [Gaya 2010:359].
}

Esa «verdad misteriosa», que el documento no emana, necesita el cuerpo del espectador, un viviente a quien ciertos cuadros interpelan. En este sentido Ramón Gaya encarna con mucha antelación el tipo de interpretación que plantean los estudiosos del Iconic Turn, proponiéndose integrar en el mismo modelo hermenéutico la imagen y la palabra. Según Horst Bredekamp la fuerza de la imagen sale de un estado de latencia para involucrar la percepción, el pensamiento y la conducta 
del espectador. El acto icónico no se concibe separado del lenguaje. La imagen y el habla interactúan, influyen la una en la otra [2015:38]. Entonces son las imágenes las que interpelan al espectador. Enfocadas más como presencias que como representaciones, las imágenes se consideran sujetos de acción en lugar de objetos de estudio. W.J.T. Mitchell, un pionero en este ámbito disciplinar, afirma que las imágenes llevan las marcas de la personalidad y de la animación, nos hablan de manera literal y figurada, y no presentan solo una superficie («surface») sino una cara («face») que encara («faces») al observador [2005:30]. Finalmente Hans Belting, en un articulo que actualiza su volumen Antropología de la imagen, observa que somos nosotros quienes animamos las imágenes «con el fin de experimentar las imágenes como vivas. Esta animación es nuestra responsabilidad, al igual que el deseo de nuestra mirada es responsabilidad de un medium dado» [2015:157]. Desplazando la atención hacia el destinario de la imagen y sus reacciones, si se trata de pintura el planteamiento del Iconic Turn contrasta con el de una historia del arte tradicional, basada en la evolución de los estilos, en la lista de nombres famosos, en el análisis filológico de las obras etc. Es el mismo tipo de conocimiento que Ramón Gaya ha repudiado con vehemencia toda su vida. Desde su enfoque metafísico, los expertos del arte son incompetentes por situarse ante el cuadro como si fuera un objeto. En una entrevista de 1996, Juan Manuel Bonet le pregunta qué le reprochaba a la crítica. La respuesta sintetiza de forma apodíctica lo que el pintor había escrito en varios textos y profundizado en Naturalidad del arte (y artificialidad de la crítica), publicado ese mismo año [Gaya 2010:929953]. Todo gira alrededor de su concepción de la pintura como presencia viva que, desde su punto de vista, no es lícito someter a juicios estéticos:

\footnotetext{
El crítico "entiende" de una cosa que no comprende. El suyo es un oficio raro y extraño, insensato, un oficio que no responde a una verdadera necesidad, sino a una necesidad artificial, a una pseudonecesidad. La decisión de hacerse crítico de arte es una decisión disparatada, pues parte de un error de principio, el de creer que la obra de arte es una demostración del talento de su autor, que exige un especialista, un entendido para ser comprendida, en lugar de ser comprendida y aceptada como un ser vivo, como una manifestación de la vida. Sobran los estudiadores, los analizadores, los examinadores, los enjuiciadores del arte. Sin esa clase de "entendidos", la Historia del Arte podría ser otra cosa [Gaya 2007:369].
}

He aquí un ejemplo de aquella vituperación que Antoine Compagnon define como un rasgo del estilo dogmático y vociferador, propio de los antimodernos [2007:239]. Con esta paradoja Ramón 
Gaya rechaza el rigor de la interpretación histórico-filológica, un conocimiento que llegaría a ser controvertido también en esos ámbitos culturales que lo han marginado y de los cuales nunca quiso formar parte. En tiempos postmodernos y globalizados la legitimación de la historia del arte ha entrado en crisis en cuanto parte de esos grandes relatos de la tradición occidental que han dejado de ser prescriptivos [Lyotard 1987]. El que se ha llamado el renacimiento de la imagen, con las características activas que le atribuyen los Visual Studies, rebasa la hegemonía metodológica y normativa de este saber institucionalizado. El poder de la imagen — también de la imagen pictórica— se ha desplazado a la visión del espectador, en un cruce de miradas que pertenece a un contexto cultural, a una sociedad históricamente determinada. Es un planteamiento que ayuda a encuadrar la heterodoxia metafísica de Ramón Gaya, su actitud de sumisión devota ante las obras que considera valiosas. A Nigel Dennis que lo entrevista en 1983, el pintor aclara que contemplar un cuadro implica una espera:

\footnotetext{
Quiero decir que uno debe estar delante de la obra lo más despojado de sí mismo que pueda, y recibir la obra, que la obra le llegue a él. Porque las obras van en busca nada más que de aquellas personas que las esperan limpiamente, no de las que se enfrentan a ellas y les echan cosas —ideas, teoríasencima [Gaya 2007:224].
}

En contra de la que considera una petrificación del arte, el pintor les otorga a los cuadros una voluntad propia. En El sentimiento de la pintura dice que existen «para sumarnos a su vida, para enamorarnos, para hechizarnos, para vencernos si fuera preciso» [2010: 32. Cursiva del autor]. De manera análoga los anima W.J.T. Mitchell, pero esgrimiendo la que él Ilama a «secular divination» [2005:26] contra los iconoclastas de nuestro tiempo. Tras la huida de los dioses, las proyecciones del deseo que suscitan las imágenes atañen laicamente al funcionamiento actual de la cultura.

\section{De exilio en exilio}

Casi no hay página sobre Ramón Gaya que no mencione sus famosos homenajes, si bien la función del documento — catálogo, postal, foto etc.—que el artista pinta en sus cuadros hasta el final de su vida merece alguna observación ulterior. En principio la presencia del documento es justificada por la distancia, declinada en todas sus acepciones, reales y simbólicas. Cuando Ramón Gaya se embarca en el Sinaia, rumbo al exilio mexicano, en el diario colectivo de la travesía escribe el artículo «La 
pintura mexicana (Lo que sé de vosotros)». La impresión de que es un arte impulsado por una "gran fuerza primaria» [2010:778] se basa en las reproducciones, los documentos que lo introducen a la cultura pictórica del país que lo acogerá. Otra vez una proyección imaginaria destinada a disiparse al estar allí. Esta dinámica entre la imagen reproducida y el original materializado, entre la prefiguración de la obra y su visión efectiva, había estructurado la pintura de Ramón Gaya desde que vivía en Murcia, antes de viajar a París por primera vez. La diferencia, ahora, es que la toma de distancia ha sido impuesta por el exilio. La imaginación de lo inalcanzable, la fábrica de presencias evanescentes se convierte en una experiencia ineludible y dolorosa.

Llegado a México con ni siquiera treinta años, Ramón Gaya vive un exilio dentro del exilio. Está de luto y a él no le interesa hablar de la guerra, como la mayoría de los exiliados españoles. Tampoco le interesa la pintura muralista una vez que la ha visto de cerca. Sus opiniones francas en el campo del arte mexicano desatan la hostilidad de Diego Rivera, que llega a pedir que se le expulse del país. Ramón Gaya vivirá aislado, viendo a pocos amigos. De aquella desolación surgen sus homenajes, lieux de mémoire o palimpsestos que Ilevan inscritas pérdidas sobre pérdidas. Es especialmente interesante cómo los recuerda el pintor al cabo de mucho tiempo, con balances que atan el arte a la vida en un vínculo férreo. Por ejemplo, en la larga entrevista con Elena Aub, de 1981, pone en relación los homenajes con la pintura contemporánea y con su propia manera de mirar al pasado:

\footnotetext{
La creación es un algo vital que hay en el hombre - lo hay desde las cuevas, claro-y es un hilo que no se puede romper. Esa es la polémica que yo tengo con el arte contemporáneo. Yo no quiero pintar como se ha pintado en el pasado, no es eso; lo que quiero es no apartarme del camino natural. Es en México donde empiezo a pintar eso que yo llamo homenajes. Al vivir rodeado de reproducciones, siempre tenía una u otra reproducción sobre una mesa, entonces colocaba en torno unos objetos y creaba una atmósfera en torno a esa reproducción; era mi manera de comunicarme con la pintura de siempre, era una actitud polémica, polémica sin gritos [Gaya 2007:181].
}

Con razón Muñoz Millanes afirma que las reproducciones eran para el pintor «una prótesis de la memoria. Al no disponer de la singularidad del original, la reproducción le servía para recordar aspectos suyos que ella no había captado, pero que él había apreciado en su visión directa del cuadro» [2012:57]. Una prótesis que él pinta como parte imprescindible del cuadro. En México la imagen del documento remite a una distancia cargada de pathos. Nótese cómo estos homenajes no presentan 
nunca una versión entera o parcial del cuadro elegido, no se limitan a la interpretación personal de la pieza homenajeada. Junto con los objetos cotidianos que remiten al hábitat del viviente, Ramón Gaya le da carta de existencia pictórica a la propia reproducción, al documento. La imagen de la lámina, la postal, la página de un catálogo enseñan la pieza añorada y a la vez marcan la distancia con respecto al original, guardado en los museos de Europa.

Destaco el caso sintomático del Homenaje a Velázquez de 1948, el que reproduce un fragmento de El niño de Vallecas de Velázquez, un cuadro que Ramón Gaya volvería a pintar después del exilio mexicano, pero con variantes menos sombrías o melancólicas. Omitiendo el resto de la figura, el pintor selecciona la parte que lo subyuga —el rostro— reduciendo el cromatismo rosado del original a una gama de grises espectrales sobre un fondo negro. La composición es esencial. El pequeño lienzo con el rostro del niño está apoyado en una repisa apenas esbozada, de color beige oscuro como la pared. Un vaso transparente con asa, de hechura popular, es el único objeto doméstico que comparte aquel espacio austero, pero tiene una posición privilegiada: está delante del cuadro, en el lado izquierdo, en primer plano. No es una casualidad el hecho de que, a partir de entonces, todos los documentos o reproducciones de cuadros que figuran en los homenajes estén detrás de la tantas veces comentada copa de cristal, por lo general parcialmente llena de agua. Es la imagen pictórica de la trascendencia de lo real. En la entrevista con Nigel Dennis, de 1983, Ramón Gaya habla de su inclinación por los objetos de cristal (no entallado) que antepone a los demás objetos a fin de mostrar una transformación in fieri. El cristal metaforiza el conocimiento como superación de los datos perceptivos, como apertura al más allá de las evidencias: «un cristal se abre sobre un abismo: el abismo de la transparencia. Allí, en ese misterio, creo que se puede entrar, como se puede entrar en un espejo también» [Gaya 2007:242]. En este Homenaje a Velázquez del periodo mexicano, el vaso transparente y el lienzo pintado con un estilo borroso forman un montaje en abîme: el pintor pinta un cuadro que reproduce otro cuadro que a su vez es una reproducción parcial y reinterpretada. En el léxico de Ramón Gaya, «homenaje» y «nostalgia» acabarían siendo sinónimos. Tienen en común la lejanía de lo conocido, conjuran ausencias ambivalentes que hieren y consuelan. La nostalgia, que deriva de nóstos (vuelta) y de álgos (dolor), se despliega alrededor de una visibilidad denegada [Prete 1992: 9,19]. Los homenajes de Ramón Gaya nacen en México con esta marca y la guardan para siempre.

Lo llamativo es el hecho de que el pintor haya continuado haciendo homenajes cuando había dejado México definitivamente y, aunque seguía en el exilio, ya podía contemplar de cerca 
la pintura que le interesaba. No sólo: el estilo de los homenajes fundamentalmente no cambia por lo que se refiere a la reproducción del documento, es decir a la inscripción de la ausencia del original. Entonces, si en México esta figura de la distancia era también física, en Europa cobra otro sentido. La nostalgia vira, el recuerdo apunta a la aparición anhelada con otras modalidades. La clave hermenéutica está en los ensayos sobre pintura que Ramón Gaya escribe entre los años cincuenta y sesenta y también en algunos poemas. En 1999, el amigo Tomás Segovia, también exiliado en México, recordaba que para Ramón Gaya «el exilio fue casi enseguida un lugar de donde partir», puesto que «nunca se demoró en su suelo y saltó de él no a un retorno o una recuperación, sino a una vasta aventura con la pintura (y la vida) que no miraba mucho atrás» [2009:106]. La lejanía es para el pintor una vivencia cada vez más interiorizada. Veamos, a este respecto, lo que escribe en 1956, el año en que se establece en Roma. Es un texto que permanece inédito hasta la edición póstuma de la Obra Completa (2010). Se titula «Final de destierro», un título revelador ya que el exilio propiamente dicho no había terminado. Escribió María Zambrano que el exiliado, de destierro en destierro, acaba «desposeyéndose, desenraizándose» [1990:17]. Algo por el estilo le pasa a Ramón Gaya cuando regresa a Francia por primera vez. La memoria de la experiencia histórico-política está silenciada, solo deja constancia del reencuentro con la pintura, que sin embargo no es el que se esperaba. También en este caso no deja de recordar que las reproducciones son un soporte de la memoria necesario y a la vez despreciable:

\footnotetext{
El 21 de junio de 1952, después de largos años, volvía de nuevo a Europa. Me encontraba, de pronto, en París, y esa misma mañana de mi llegada entraría en el Louvre, impaciente, como hambriento, muy emocionado, casi tembloroso aunque radiante, y también... un poco triste: "Todo es triste al volver". Por muy determinadas circunstancias, desde 1936 no había podido contemplar directamente, en su ser real y verdadero, un solo cuadro de Tiziano, de Rembrandt, de Velázquez, de Murillo o de Rubens, sino viles reproducciones suyas estampadas, "imaginarias", algunas incluso bastante... buenas —mil veces más engañosas que las decididamente detestables-, y ahora, por fin, parecía que terminaba de una vez esa forzada abstinencia que durante muchos años vino a constituir mi verdadero exilio [Gaya 2010:887].
}

Junto con la alusión a la pintura como patria ideal, que rebasa las fronteras nacionales, destaca el uso funcional del documento durante la estancia mexicana. El hecho de representarlo en los homenajes que había pintado allí, remite al estado de privación del pintor alejado de sus 
piezas favoritas. Sin embargo, el final de la abstinencia forzada no restituye el apego incondicional. El desterrado que regresa precipita en otro destierro, metafórico, producido por el museo en cuanto institución. Tras esta premisa, a continuación Ramón Gaya recuerda la decepción del reencuentro, un topos del exiliado cuyo mal no se cura con el regreso. La nostalgia no cesa porque el remedio no será jamás suficiente [Jankélévitch 1974:293]. Es lo que el pintor averigua a su pesar entrando en el museo del Louvre:

\footnotetext{
21 de junio, por la noche. Mi primera impresión esta mañana al entrar en el Louvre fue más bien de destartalo y de vacío, ese vacío que se produce, precisamente, en los lugares muy llenos de cosas, de trastos, de artefactos; un vacío diríase, como corpóreo, un vacío de museo, consustancial al museo, la musealidad misma hecha cuerpo presente, esa presencia muerta, hueca de lo museal que, olvidada y perdida de vista durante años, ahora me la tropezaba intacta otra vez. De unas salas a otras buscaba, ansioso, los seres vivos, los amigos vivos que sabía encerrados allí, pero solo topaba con ese huevo compacto de la Historia del Arte; todo estaba agrupado por escuelas, por épocas, por estilos, por países; me perdía, pues, como se pierde uno en los mapas, y de ahí que pasara, muy tranquilamente y sin sentir, por delante de tal lienzo de Tiziano o de tal otro de Rubens, ya que estos seres, que yo sabía existentes y únicos, se me quedaban ahora como emborronados, traspapelados; éste, en el "colorismo" y en las mal Ilamadas "propiedades táctiles" de la pintura veneciana, y el otro, en la plebeya "carnalidad barroca" de la pintura flamenca. Me marchaba de mal humor, disgustado, casi defraudado; incluso llegué a decirme que, desde lejos, en el largo periodo de abstinencia, había quizá fantaseado demasiado, y que todas esas criaturas absolutas que yo soñara durante mi exilio no existían en realidad, en la realidad de la pintura; en lo porvenir no tendría, pues, más remedio que conformarme con esa idea de un arte...artificial, estético, hecho, compuesto, como siempre había visto que, más o menos, lo concebían todos, es decir, no tendría más remedio que aceptar —aunque ello me hundiera en una especie de desgana, de desesperanza - esa idea tan triste que concibe la obra de arte como un producto elaborado, ingeniado, del espíritu, del endiablado juego del espíritu [Gaya 2010:887-888].
}

Comparemos las fechas. Este texto se refiere a 1952, pero está escrito cuatro años más tarde, después que el pintor ya había hecho en Venecia su gran descubrimiento, promoviendo La Serenissima - como le gustaba Ilamarla, con el epíteto de cuando era una república poderosa- a lugar originario de la pintura. En el diario anota las bases del que sería, desde entonces hasta el final de su vida, el discurso sobre la pintura como arte des-artizado, pero en un sentido opuesto al que teorizaría Adorno en su Teoría estética, publicada póstuma en 1970. Para el filósofo alemán la desartización descalifica la obra de arte, pues «se convierte en una cosa más y en un vehículo de la piscología del contemplador» [2004:31]. Hay desartización cada vez que se pierden las cualidades 
tradicionales de la obra de arte [Vilar 2010], justo esas cualidades de las que Ramón Gaya reniega al convertir la pintura en un ente vivo que aparece en los cuadros del pintor-creador.

El amigo José Bergamín, que ya arremetía contra la estética en los años veinte, respalda totalmente la heterodoxia metafísica de Ramón Gaya. En una miscelánea de 1962, titulada Al volver, refiriéndose al museo del Prado afirma Bergamín que los cuadros «son revelación, por la pintura, de una realidad invisible; hay aparición y no solamente apariencia pictórica», mientras que la crítica que sitúa históricamente una obra, acaba «apagando su revelación viva, envolviéndola como en un sudario mortal en las sombras infernales del tiempo» [Bergamín 1962:193-194]. Dos años antes, en la exposición que Ramón Gaya hace en Madrid la primera vez que regresa a España, publicando simultáneamente en español El sentimiento de la pintura —un doble acontecimiento que no tendrá la menor repercusión—, Bergamín le da la bienvenida al amigo pintor hablando de los cuadros y del libro con el mismo planteamiento, ya que «el arte es su aparición y no su apariencia o parecido» [Gaya 2016:601]. Patria idealizada que no admite competencia talentosa ni voluntad estética, la pintura que Ramón Gaya realiza mientras vive en Italia y también después de regresar a España se nutre de esa trascendencia. En contra de la muerte de la pintura tantas veces representada por las vanguardias, observa con clarividencia José Luis Pardo que los cuadros de Ramón Gaya son, por un lado, «como instantáneas que representan una y otra vez el nacimiento de la pintura, ese lugar donde podría nacer la pintura, donde se encuentra al borde del ser»; por otro lado, son una forma de bienvenida «a la pintura misma, como un acto que invoca su regreso no a modo de un "retorno" de algo ya sucedido en algún tiempo pretérito, sino como el advenimiento de un suceso que nunca ha llegado a ocurrir del todo y con respecto al cual el cuadro es un símbolo de esperanza» [Pardo 2006:71].

Volvamos pues al documento constantemente presente en los homenajes, es decir al catálogo, a la foto, a la postal, a cualquier tipo de reproducción de la obra evocada dentro del propio cuadro en un escorzo doméstico: la casa de la vida coincidiendo con el lugar de la pintura. Inscrito en el homenaje, el documento enseña el deseo que pone su objeto en un más allá sagrado que se renueva una y otra vez. Es un recordatorio, una llamada visual a la íntima vivencia de una búsqueda (o quête) que no tiene fin. Entre los ejemplos incontables, una muestra extraordinaria es el Homenaje a un dibujo de Tiziano, de 1965, donde la aparición es un fenómeno figurativo que materializa la idea. Ramón Gaya había contemplado el Ritratto di giovane donna de Tiziano en la Galería de los Uffizi de Florencia, mientras estaba viviendo en Roma, es decir muy cerca de aquel museo, fácilmente 
accesible. Sin embargo pinta este homenaje como de costumbre, es decir insertando en un gouache el documento que marca una distancia ya simbólica, intencional. El dibujo reproducido no retoma el color marrón claro de la cartulina original, puesto que no es la mímesis la que está en juego. La hoja que lo representa, apoyada verticalmente contra una pared, es muy clara y la figura retratada es tan evanescente que apenas se divisa. En realidad, podría ser la silueta o el rastro que deja tras sí la joven retratada al abandonar el dibujo para aparecer a tamaño real —el volumen verosímil de un cuerpo femenino- en la habitación del pintor. Con su lujoso vestido renacentista, aquella aparición ha salido al encuentro del pintor que la espera, ha llegado a su casa, apoya el codo izquierdo en un lado del mueble que contiene una composición típica de los homenajes, la firma reconocible de Ramón Gaya. Sobre una tela refinada de un apagado color granate, una cita cromática de Ticiano o de la pintura veneciana, hay varios objetos transparentes — un cuenco, un florero diminuto, una vistosa copa con agua en primer plano- - dos granadas y una pequeña rosa del florero que hacen juego con el color de la tela. Esta base granate contrasta con el ocre claro que domina el resto del guache: la figura de la joven y el fondo de la composición están sumergidos en la misma luz que realza el fenómeno de la encarnación. Comentando este homenaje, Nigel Dennis se pregunta: «¿Qué sentido cabe asignar a este curioso desdoblamiento?» [2010: 200]. En mi opinión, me parece una de las realizaciones más explícitas de la concepción de la pintura como vida que le sale al encuentro del pintor que está a la espera. A partir de entonces, los tonos cálidos del ocre caracterizan con frecuencia creciente la mayoría de los homenajes, en particular si el sujeto que aparece es religioso, con el IV Homenaje a Murillo. (S. María del Mar) y La Verónica de Salzillo (1975) a la cabeza. En general, el arte de Ramón Gaya tiende a ser cada vez más diáfano.

En una de las anotaciones inéditas, que hoy pueden leerse en la Obra Completa, el pintor había aclarado cuál era su relación con las obras de los pintores admirados: «Lo que hago a partir de los cuadros de otros, no es ni por asomo una interpretación. Ni, como dije alguna vez, un comentario, sino una visión, claro, personal pero respetuosa, es decir, una visión equidistante entre la subjetividad y la objetividad» [2010:537-538]. Esa visión diferencia, distingue, abre huecos, prepara el lugar intermedio donde la pintura va a aparecer, como dice un terceto iluminante del soneto Mansedumbre de obra: «Lo pintado no es nada: es una cita / — sin nosotros, sin lienzo, sin pintura— / entre un algo escondido y lo aparente» [Gaya 2010:636]. No extraña que, a medida que pasan las décadas, sus homenajes apunten cada vez más al non finito, al esbozo difuminado sobre el fondo blanco, sin 
pintar. En 1996, con 86 años y una gran obra acumulada, Ramón Gaya le confiesa a Pedro Soler, que lo entrevistaba, no haber llegado aún a la meta ansiada:

\footnotetext{
Lo que sucede es que casi nunca estoy conforme con lo que hago. Yo no abandoné el cubismo para dedicarme al realismo, porque no soy un realista. Lo que yo he querido siempre es lograr expresar la realidad, el secreto de la realidad, y no es fácil lograrlo. Siempre he pensado que en mi obra ese encuentro con la realidad podría ir más allá. Pero esas 'copicas' de cristal a las que aludes representan no sólo algo en sí mismo, sino toda la realidad. Yo espero hasta ver de descubrir el misterio [2007:362-63]
}

Las citas de los homenajes de Ramón Gaya no tienen nada que ver, entonces, con la estética de la cita que estalla en el campo de las artes visuales a partir de los años sesenta del pasado siglo, cuando lo nuevo de las vanguardias parece haber llegado a su fin. En ese caso, citar obras maestras implica un confronto sobre cuestiones de estilo, originalidad y autoría, valorando el gesto metapictórico del artista. Es este el caso, por ejemplo, de las múltiples versiones cubistas de las Meninas que hace Picasso o de los retratos informales de Goya que pinta Antonio Saura. Los homenajes metafísicos de Ramón Gaya son más excéntricos todavía con respecto a la postmodernidad y a un movimiento como el de la Appropriation Art, cuando sobre las cenizas de las vanguardias se anulan diacronías y jerarquías con montajes que deforman los originales dentro de las copias. En ámbito español, recuerdo las versiones de las Meninas del Equipo Crónica (Manolo Valdés y Rafael Solbes), que toman como modelo el pop art americano pero con finalidades políticas, ya que en España había que acabar con los mitos nacionalistas del franquismo. Por el contrario, no hay tal compromiso en el neoyorkino Roy Lichtenstein que se cita a sí mismo en el grabado Two Paintings: Sleeping Muse, de 1984. La pieza representa el fragmento de un grabado con marco, cuyo referente es una de sus propias esculturas, la cabeza de metal Ilamada Sleeping Muse, también reproducida con variantes de postura y tamaño. La meta-auto-pintura no es algo nuevo, baste recordar lo que hace Édouard Manet en El retrato de Émile Zola, de 1868. En todo caso se trata de estéticas antagónicas a la concepción y a la práctica de la pintura de Ramón Gaya. 


\section{«En forma de fantasma»}

En este pintor captar la visión trascendente es un proceso aún más Ilamativo cuando atañe a cuadros jamás vistos en persona. Una vez más, el documento pictórico juega un papel decisivo. A este propósito, Muñoz Millanes supone que

\footnotetext{
la reproducción no siempre es una simple estampa plana y fija, pues circunstancialmente permite apreciar la riqueza de un original con el que aún no se ha tenido contacto directo. Este sería el caso de Cézanne, en la juventud murciana de Gaya, y de la pintura holandesa. Y sobre todo de la oriental, en la que, antes de volver a Europa, él pudo profundizar exclusivamente gracias a las reproducciones [2012:58].
}

Para abordar una cuestión tan enrevesada veamos un testimonio del proprio pintor, que en sus cartas deja constancia de este tipo de experiencia. En diciembre de 1951, desde Cuernavaca Ramón Gaya le escribe estas líneas a su joven amigo mexicano Salvador Moreno —músico, historiador de arte y pintor - que está en Nueva York por primera vez: «Estás en una posición privilegiada: viviendo exactamente — corregido y aumentado— lo que tú sabías. Lo sabías, pero dudabas de su existencia, puesto que hasta ahora sólo se te había entregado en forma de fantasma. De ahí tu odio a las reproducciones de cuadros y fotografías de lugares» [2016:218. Cursiva del autor]. En marzo de 1952, desde la misma ciudad y a punto de salir para Francia, Ramón Gaya le escribe nuevamente al amigo que ya está en París: «¡Cómo te envidio esa exposición de dibujos; Rembrandt, Rubens, me parecen ya, desde aquí, fantasmas que yo mismo me he inventado!»[2016:226]. Sin duda se había inventado el fantasma de un cuadro que no había visto más que una reproducción como Las cortesanas de Vittore Carpaccio. Así las había Ilamado John Ruskin, pero se conocen ahora como las Dos damas venecianas, después que en los años '90 del pasado siglo se descubrió que el cuadro es incompleto. Forma parte de un panel, cuya parte izquierda está en el Getty Museum de Los Ángeles y se titula Caza en la laguna [Szafran 1995:148-158]. Entonces Ramón Gaya no podía saberlo y en México pinta el Homenaje a Carpaccio, de 1951, esbozando una mímesis de la reproducción, pues lo inacabado es para él la modalidad del aparecer. El catálogo que reproduce el cuadro está abierto verticalmente y apoyado contra una pared. La base —una cómoda o una repisa — está cubierta con una tela clara. En el lado izquierdo, apoyado al libro, un abanico remite a otros fantasmas, los del arte oriental. Delante de ambos una gran una copa de cristal con agua metaforiza la transparencia 
a partir de la huella fotográfica del objeto ausente. En primer plano, completan el montaje de objetos familiares dos granadas, una de ellas abierta con sus frutos rojos a la vista. La iconografía de la granada es vasta: entre las culturas paganas de la antigüedad se la asocia a Astarté, a Deméter y Perséfone, a Afrodita y Atenea, a Juno; en época cristiana remite a la sangre de los mártires, a la caridad misericordiosa, a la iglesia como institución, a la pureza de la Virgen. Hay muchas citas culturales reunidas en este cuadro. Al igual que los otros homenajes, este también enseña una lógica del montaje que recuerda el archivo de Aby Warburg y sus pathosformeln, junto con la constelación de imágenes de Walter Benjamin [Pintor Iranzo 2017]. El homenaje a Carpaccio, que no representa el cuadro sino la reproducción, configura la mitificación de la nostalgia. En efecto, echa de menos el rincón de patria o pintura que no ha perdido, ya que nunca ha podido enlazar con ella una relación directa, es decir estar delante del cuadro. No deja de sorprender el hecho de que, al poner pie en Venecia por primera vez, Ramón Gaya no acuda a ver a su admirado Tiziano. Se precipita a averiguar el original de la obra que había visto solo «en forma de fantasma», Ilevándose una sorpresa exaltante. Se la cuenta en seguida a Tomás Segovia en una carta del 16 de julio de 1952:

\footnotetext{
Esta tarde fui a ver, exclusivamente, Las cortesanas de Carpaccio. No he visto nada más de pintura, pues quiero aprovechar estos días — hasta el 19-, en que estoy solo, para pintar. El Carpaccio es maravilloso, más, mucho más de lo que imaginaba; la reproducción —excelente como reproducción en sí (como diría Gaos) pero, claro, falsísima, más brillante de color, más descarado todo, más burdo- no tiene nada que ver con el cuadro. El cuadro - no grande, sino como tu retrato, a lo sumo- está mucho más apagado, no sólo de color, sino de expresividad, pero a cambio de eso, tiene mucha más vida, una vida tan silenciosa, tan secreta, que casi da miedo; aquellas dos mujeres, tan melancólicas, dan la sensación de algo intocable, sagrado, que tratándose como se trata, de unas cortesanas, resulta como de un significado indescifrable — quizá sin significación- muy hermoso y raro. Es un cuadro casi mustio, como una fruta un poco pasada; es un cuadro —una tabla al óleomuy quieto, Ileno de alma —eso sí, de qué manera- (lo contrario, exactamente, de la Gioconda), triste, muy recatadamente triste. La actitud de Carpaccio al pintar estas mujeres (¡claro, por eso me gustaban tanto!) es exactamente la de Velázquez al pintar los enanos, y sobre todo, al Niño de Vallecas [2016:245-247. Cursiva del autor].
}

Ramón Gaya experimenta el cortocircuito temporal puesto en marcha por el cuadro, que disuelve el fantasma de su homenaje. Pero la cosa no termina allí, la nueva visión se ensancha. El cuadro de Carpaccio emana el aura de lo sagrado, le depara una experiencia trascendente, hace 
aflorar la que George Didi-Huberman ha llamado — a propósito de Aby Warburg y de su concepto de Nachleben - la imagen-fantasma de un tiempo inactual. Son las huellas sintomáticas y anacrónicas que «no se calcaban ya sobre la transmisión académica sino que se expresaban por obsesiones, "supervivencias", remanencias, reapariciones de las formas. Es decir, por no-saberes, por impensados, por inconscientes del tiempo» [2009:25]. Frente al cuadro de Carpaccio, Ramón Gaya sutura el ahora veneciano con el entonces español, el tiempo anterior al exilio, cuando podía ir al Prado siempre que quería. En presencia del cuadro de Carpaccio, deshecho el fantasma del homenaje, emerge el fantasma latente por excelencia, un cuadro de Velázquez especialmente querido. La asociación con el pintor sin iguales pone en marcha un proceso anacrónico que se sustrae a la historia del arte. Reaparece el injerto impensado, la imagen superviviente, espectral, errática: El niño de Vallecas, la cifra iconológica de la trascendencia. Muchos años más tarde, en Velázquez, pájaro solitario, Ramón Gaya afirma que «El niño de Vallecas es todo él como una elevación, como una ascensión. Todos los retratos velazqueños vienen a ser como altares, pero El niño de Vallecas es el altar mayor de su obra desde donde poder saltar, pasar al otro lado, más allá de todo» [2010:120]. Este cuadro da acceso a la visión de la pintura como ente con vida, energía que no para de transitar. Ese retrato acude a la cita con lo trascendente cada vez que Ramón Gaya, siempre a la espera, lo vuelve a pintar. Así recibe el legado y lo trasmite dándole una forma, siempre provisional en su actualización.

Al igual que su pintura, cada vez más exenta de imágenes definidas, con el paso del tiempo la escritura de Ramón Gaya casi prescinde de explicaciones. La una y la otra podrían resultar herméticas si no se contextualizaran en el camino trenzado que las vuelve asequibles dialécticamente, en el cauce metafísico que también forma parte de una modernidad marginada. Lo real es pensado de manera trascendente a través del arte pictórico y viceversa, en un vaivén interminable. En la entrevista de 1983, a Nigel Dennis que le pregunta que qué se propone cuando escribe, Ramón Gaya contesta:

\footnotetext{
Cuando yo escribo — como no soy novelista, ni soy propiamente poeta - escribo casi siempre, como tú sabes, sobre arte. No son ensayos exactamente, ni es que a mí me guste teorizar. Lo que pasa es que, en fin, pienso y he pensado siempre sobre el arte delante de las obras, o leyendo a Tolstoi o a Nietzsche, es decir, leyendo libros que a mí me han gustado y siguen gustándome porque son cosas decisivas [2007:220].
} 
Habría que añadir que pensaba también delante de las reproducciones de los cuadros, cosas no menos decisivas ya que el fin de su arte es darle consistencia visible al más allá de lo real, a lo trascendente. Ambas dimensiones son indisociables y cooperan incesantemente. Si no está oculto, ese objeto del deseo y móvil de la forma no se puede evocar, no hay posibilidad de que aparezca.

\section{Conclusiones}

Definir la modernidad es una cuestión abierta también gracias a artistas como Ramón Gaya, que no caben del todo ni en los marcos conceptuales más inclusivos, los que apuntan a abarcar «los caminos que no tomó la historia» [Compagnon 2007:14]. Sin duda él no tiene los rasgos pertinentes de esa retaguardia que, por oposición a las vanguardias históricas, defiende la tradición estética, el historicismo, la genialidad creadora, la política elitaria y nacionalista (Marx 2008). Su biografía de exiliado republicano es el mejor testimonio al respecto, pues a partir de sus peregrinaciones acaba llevando a cabo una profética ruptura de rupturas. No la funda en la lógica de la superación y del reemplazo de modelos, propia del canon de la modernidad. La encamina hacia una metafísica de la pintura que apunta a la aparición, al advenimiento de lo originario y perenne ante un sujeto concebido etimológicamente como subjectum, alguien que está "sometido", "puesto debajo". En su caso, un creador al servicio de la pintura invocada como presencia viva, visión sustraída a un fluir oculto e incesante, imagen que aflora en el cuadro como presencia trascendente. El eje sensible de este proceso es el cuerpo del pintor y su hábitat, la experiencia encarnada y emocionante del fenómeno artístico que Ramón Gaya aborda con singular inventiva metafórica —el lenguaje de lo sagrado— en todos sus escritos, entre los cuales El sentimiento de la pintura constituye el texto fundacional.

Pasó desapercibido, al igual que su pintura, cuando lo publicó en Italia y en España, en 1960. Habrá que esperar que los "ismos" se institucionalicen y se ponga en tela de juicio la hegemonía de la historia del arte para poder apreciar la modernidad heterodoxa de Ramón Gaya, cuya práctica artística y cuyo pensamiento acerca de la pintura realzan el papel activo, subyugante de la imagen. Exceptuando el paradigma metafísico, próximo a la filosofía de María Zambrano, a este propósito la actitud de Ramón Gaya guarda hoy muchas afinidades con el planteamiento de los Visual Studies. En particular, destacan los Homenajes que él empezó a pintar como evocaciones nostálgicas de la pintura europea, durante los años mexicanos, y que luego convirtió en la cifra identitaria de su pintura, su 
manera de propiciar con la ceremonia de montajes la revelación ansiada. En los Homenajes juega un papel fundamental el uso icónico del documento - el catálogo, la postal, la foto, el boceto en el cuadro etc.- que reproduce sumaria y parcialmente la pieza del pintor admirado, junto con pocos objetos de la vida cotidiana. Con esta metapintura minimalista y siempre inacabada, en el contexto de reducidos escorzos domésticos, Ramón Gaya muestra que hay una compenetración diaria entre su vida de pintor y la vida de su pintura. El documento que reproduce los cuadros favoritos es el dispositivo que cumple con la doble función de archivar el recuerdo y alimentar el deseo. Simbólicamente, el documento materializa para los ojos lo que siempre falta: el trabajo de la memoria, la condición de la espera.

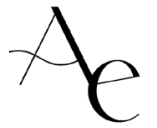




\section{BIBLIOGRAFIA}

ADORNO, Th. W.: Estética, Obra Completa, 7. Madrid: Akal, 2004.

AGAMBEN, Giorgio: «El lugar de la poesía. Aproximaciones a la poesía de Ramón Gaya», en Ramón Gaya, La hora de la pintura, Barcelona, Fundación Caixa Catalunya, 2006, pp. 49-57.

—_: «¿Qué es lo contemporáneo?», en Desnudez, Barcelona, Anagrama, 2011, pp. 17-27.

: Autoritratto nello studio. Milán: nottetempo, 2016.

BARTHES, Roland: La cámara lúcida. Barcelona: Paidós, 1989.

BELTING, Hans: «Imagen, medium, cuerpo: un nuevo acercamiento a la iconología», CIC Cuadernos de Información y Comunicación, 20 (2015), pp. 153-170.

BERGAMIN, José: Al volver. Barcelona: Seix Barral, 1962.

BONET, Juan Manuel: Diccionario de las vanguardias en España (1907-1936): Madrid: Alianza, 1995. : «Una copa de agua», en Una copa de agua, [Murcia], Museo Ramón Gaya - Fundación Santander, 2005, pp. 45-54.

— : 2006: «Ramón Gaya: una travesía del siglo», en Ramón Gaya, La hora de la pintura, Barcelona, Fundación Caixa Catalunya, 2006, pp. 11-35.

BREDEKAMP, Horst: Immagini che ci guardano. Teoria dell'atto iconico, Edizione italiana a cura di Federico Vercellone. Milán: Raffaello Cortina, 2015.

COMPAGNON, Antoine: Los antimodernos. Barcelona: Acantilado, 2007.

DANTO, Arthur C.: Después del fin del arte. El arte contemporáneo y el linde de la historia, $4^{\mathrm{a}}$ ed. Paidós: Barcelona - Buenos Aires - México, 2014.

DENNIS, Nigel: «En torno a los homenajes de Ramón Gaya», Turia, 95 (2010), pp. 225-232.

DIDI-HUBERMAN, Georges: La imagen superviviente. Historia del arte y tiempo de los fantasmas según Aby Warburg. Madrid: Abada Editores, 2009.

DI GIACOMO, Giuseppe: Fuori dagli schemi. Estetica e arti figurative dal Novecento a oggi. RomaBari: Laterza, 2015.

DURANTE, Laura Mariateresa: Ramón Gaya, el exilio de un creador. Roma: Edizioni Nuova Cultura, 2013. : «La Venere sporca di Ramón Gaya», en Ramón Gaya, // sentimento della pittura, Traduzione, note e introduzione di Mariateresa Durante, Presentazione di Ana María Leyra, Chieti, Solfanelli, 2015, pp. 13-61. 
FERRARIS, Maurizio: «La revolución documedial», Revista de Occidente, 434-435 (julio-agosto 2017), pp. 9-47.

GAYA, Ramón: De viva voz. Entrevistas (1977-1988), Selección y presentación de Nigel Dennis. Valencia: Pre-Textos, 2007.

_- Homenaje a la pintura, Institut Valencià d'Art Modern, del 10 de junio al 5 de septiembre de 2010. [Madrid]: Sociedad Estatal de Conmemoraciones Culturales, 2010.

— : Obra Completa, Edición al cuidado de Nigel Dennis e Isabel Verdejo, Prólogo de Tomás Segovia. Valencia-Madrid: Pre-Textos - Sociedad Estatal de Conmemoraciones Culturales, 2010.

——: Cartas a sus amigos, Prólogo de Andrés Trapiello, Edición de Isabel Verdejo y Nigel Dennis. Valencia: Pre-Textos, 2016.

GARGANI, Aldo G.: Lo stupore e il caso: Roma-Bari: Laterza, 1986.

HARTOG, François: Regímenes de historicidad: presentismo y experiencias del tiempo. México: D.F., Universidad Iberoamericana C.M., 2007.

HEIDEGGER, Martin: Ser y tiempo. Santiago de Chile: Editorial Universitaria, 2002.

JANKÉLÉVITCH, Vladimir: L'irréversible et la nostalgie. París: Flammarion, 1974.

LONGHI, Roberto: «Momenti della pittura bolognese», en Da Cimabue a Morandi, Saggi di storia della pittura italiana scelti e ordinati da Gianfranco Contini, Milán, Arnoldo Mondadori, 1973, pp. 191-217.

LYOTARD, Jean-François: La condición posmoderna. Madrid: Cátedra, 1987.

MARIN, Louis: Des pouvoirs de l'image. París: Seuil, 1993.

MARX, William (ed.): Les arrière-gardes au XXe siècle. L'autre face de la modernité esthétique. París: PUF, 2008.

MITCHELL, W. J. T. : What do pictures want? The Lives and Loves of Images. Chicago - Londres: The University of Chicago Press, 2005.

MORENO AGUIRRE, Miriam: Ramón Gaya: otra modernidad. Madrid: Universidad Complutense de Madrid, 2016. http://eprints.ucm.es/35101/

MUÑOZ MILLANES, José: Los homenajes de Ramón Gaya. Valencia: Pre-Textos, 2012.

MURCIA SERRANO, Inmaculada: Agua y destino. Introducción a la estética de Ramón Gaya. Oxford - Bern- Berlín - Bruxelas - Frankfurt am Main - Nueva York - Viena: Peter Lang, 2011.

NORA, Pierre: «Entre mémoire et histoire», en Les lieux de mémoire, t. 1, La République, París, Gallimard, 1984, pp. 23-43. 
PARDO, José Luis : «Ramón Gaya o el nacimiento de la pintura», en Ramón Gaya, La hora de la pintura, Barcelona, Fundación Caixa Catalunya, 2006, pp. 59-71.

PINTOR IRANZO, Ivan: «Formas del Atlas y el Ensayo Visual a Partir de Aby Warburg: el Montaje, la Emoción y el Gesto», BRAC, Barcelona Research Art Creation, 5 (2) ( 2017), pp. 156-188. file://localhost/. http/::dx.doi.org:10.17583:brac.2017.2684

PITTARELLO, Elide: "About Painting and Dialectical Images of María Zambrano», en Xon de Ros, Daniela Omlor (eds.), The Cultural Legacy of María Zambrano, Cambridge, Legenda, 2017, pp. 156-170.

PRETE, Antonio (a cura di): Nostalgia. Storia di un sentimento. Milán: Raffaello Cortina, 1992.

RECALCATI, Massimo: Ritratti del desiderio. Milán: Raffaello Cortina, 2012.

RICOEUR, Paul: La métaphore vive. París: Seuil, 1975.

SEGOVIA, Tomás: Gayescas. Murcia: Museo Ramón Gaya - Ayuntamiento de Murcia - Fundación Banco Santander, 2009.

SZAFRAN, Yvonne: «Carpaccio's 'Hunting on the Lagoon': A New Perspective», The Burlington Magazine, 137, 1104 (March 1995), pp. 148-158.

TISSERON, Serge: El misterio de la cámara lúcida. Fotografía e inconsciente. Salamanca: Ediciones Universidad de Salamanca, 2000.

TRAPIELLO, Andrés: «Con el permiso de Tolstoi (A propósito de la casa de la pintura en Ramón Gaya), Turia, 95 (2010), pp. 169-176.

VALCÁRCEL, José Luis: Ramón Gaya. La vida entrecortada, Prólogo de Manuel Ruiz-Funes. Murcia: Ediciones Tres Fronteras, 2011.

VILAR, Gerard: Desartización, paradojas del arte sin fin. Salamanca: Ediciones Universidad Salamanca, 2010.

WITTGENSTEIN, Ludwig: Investigaciones filosóficas, $3^{\text {a }}$ ed. México - Barcelona: Instituto de Investigaciones Filosóficas UNAM - Editorial Crítica, 2010.

ZAMBRANO, María: Notas de un método. Madrid: Mondadori, 1989.

: Los bienaventurados. Madrid: Siruela, 1990.

: Algunos lugares de la pintura. Edición, introducción y notas de Pedro Chacón. Madrid: Eutelequia, 2012. 